\title{
Effect of cimetidine on gastric secretion and duodenogastric reflux
}

\author{
R J MELVILLE, S I SULEIMAN, P F WHITFIELD, J V PARKIN, \\ $T$ O NWABUNIKE, AND M HOBSLEY \\ From the Department of Surgical Studies, The Middlesex Hospital Medical School, London
}

\begin{abstract}
SUMMARY In 19 subjects (four controls, one gastric ulcer and 14 duodenal ulcer) maximal gastric secretion was evoked with histamine $0.13 \mu \mathrm{mol} / \mathrm{kg} / \mathrm{h}(0.04 \mathrm{mg} / \mathrm{kg} / \mathrm{h})$ for two to two and a half hours. A slow intravenous bolus dose of $200 \mathrm{mg}$ cimetidine was given at the beginning of the last hour. Gastric secretion was measured before and after cimetidine administration and expressed both as mean acid output ( $\mathrm{mmol} \mathrm{H}^{+} / \mathrm{h}$ ) and 'pyloric loss and duodenogastric reflux corrected' volume $(\mathrm{Vg}, \mathrm{ml} / \mathrm{h})$. Mean reduction by acid output was $86 \%$; mean reduction by corrected volume $(\mathrm{Vg})$ was only $64 \%$. The discrepancy, which is significant $(\mathrm{p}<0 \cdot 01)$, is caused by a marked increase in duodenogastric reflux after cimetidine.
\end{abstract}

The $\mathrm{H} 2$ receptor antagonist, cimetidine, is widely used in the medical treatment of peptic ulcer disease. It is known that the primary effect of cimetidine is to competitively inhibit the stimulation, by histamine, of the parietal cells of the stomach and so reduce the amount of acid secreted.

The measurement of gastric secretion has, however, now improved so that the pyloric loss and duodenogastric reflux components of the aspirated gastric juice can be calculated separately, which allows for a more accurate determination of gastric secretion to be made. We therefore chose to re-examine the physiological effects of cimetidine on gastric secretion using this more accurate technique to improve our understanding of the function of the $\mathrm{H} 2$ receptor antagonists.

\section{Method}

\section{SUBJECTS}

Gastric secretion studies were carried out on 19 subjects. There were four controls (healthy volunteers) with no peptic ulcer disease, one gastric and 14 duodenal ulcer patients, with an age range of 26-67 years. No subject had taken any $\mathrm{H} 2$ receptor antagonist in the week before the study and no

Address for correspondence: Professor M Hobsley, Department of Surgical Studies. The Middlesex Hospital, London W1 8AA.

Received for publication 10 September 1984

Abstract presented to The British Society of Gastroenterology in March, 1980. S I Suleiman is now Associate Professor of Surgery at King Abdul Aziz University, Jeddah. subject had been previously treated surgically.

Subjects were fasted 12 hours before the start of the study. A double lumen nasogastric tube was passed into the stomach and correctly positioned for the aspiration of gastric juice as previously described, ${ }^{1}$ with the subject in a semirecumbent position. An inert marker, PSP (phenolsulphonphthalein), was infused through the smaller lumen of the nasogastric tube at a constant rate and the gastric juice was aspirated continuously through the larger lumen of the nasogastric tube and collected as ten minute samples. A continuous intravenous infusion of histamine $0.13 \mu \mathrm{mol} / \mathrm{kg} / \mathrm{h}(0.04 \mathrm{mg} / \mathrm{kg} / \mathrm{h})$ was started and maintained for two to two and a half hours. At the start of the final hour of histamine infusion a bolus dose of $200 \mathrm{mg}$ cimetidine was given by slow intravenous injection. The secretion of gastric acid was expressed as a mean acid output $\left(\mathrm{mmol} \mathrm{H} \mathrm{H}^{+} / \mathrm{h}\right)$ and a 'pyloric loss and duodenogastric reflux' corrected volume $(\mathrm{Vg}, \mathrm{ml} / \mathrm{h})$ of the aspirated gastric juice. It should be noted that $\mathrm{Vg}$ is the volume of pure gastric juice secreted by the stomach - that is, the pure mixture of acid and alkaline components. Pyloric loss was calculated from the PSP concentration in the aspirated juice and duodenogastric reflux was calculated from the sodium ion concentration in the gastric aspirate as described by Whitfield and Hobsley. ${ }^{2}$ Each maximal histamine plateau was selected with the aid of a computer program based on the aspirated volumes and PSP concentration, in an effort to restrict any observer bias. ${ }^{2}$ The first sample in the cimetidine period was 
discarded and calculations undertaken on all subsequent samples to yield mean rates of postcimetidine secretion.

\section{Results}

Figure 1 shows the gastric secretion for an actual subject in the study during the maximal histamine stimulation plateau and the period after cimetidine administration, measured both as acid output (mmol $\left[\mathrm{H}^{+}\right] / \mathrm{h}$ ) and 'pyloric loss and duodenogastric reflux' corrected volume $(\mathrm{Vg}, \mathrm{ml} / \mathrm{h})$. From acid output data, the mean reduction of acid secretion for all subjects was $86 \%$, but from corrected volume $(\mathrm{Vg})$ data the mean reduction was only $64 \%$. The difference in the mean reduction of acid secretion by these two methods of calculation is significant ( $p<0 \cdot 01$, Wilcoxon's paired rank sum).

Figure 2 shows the percentage inhibition of acid secretion after cimetidine for each subject measured as both acid output and corrected volume $(\mathrm{Vg})$. In one subject cimetidine produced no reduction in acid secretion. In two subjects there was an apparently satisfactory reduction of acid secretion by the acid output method but a less than $20 \%$ reduction by the $\mathrm{Vg}$ method. One subject showed no reduction by the acid output method but a greater than $50 \%$ reduction by the $\mathrm{Vg}$ method.

Figure 3 shows the percentage change in duodenogastric reflux after cimetidine. There is a marked increase in the volume of reflux after cimetidine $(p<0 \cdot 1$, Wilcoxon's paired rank sum). This increase

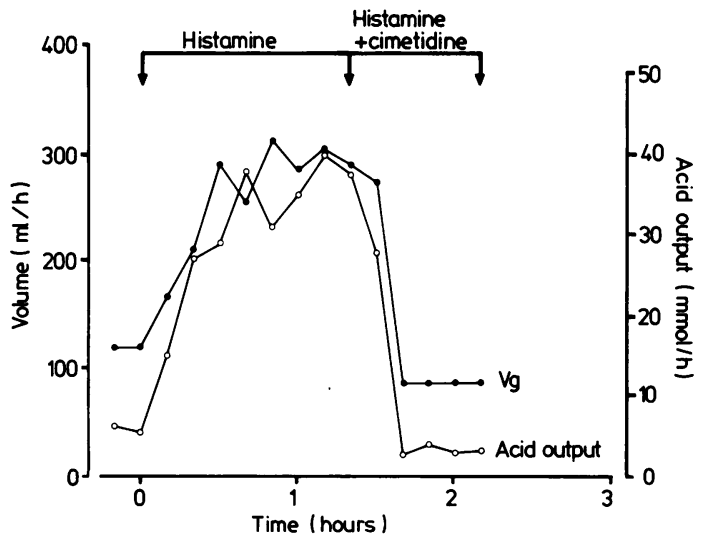

Fig. 1 Acid secretion for an actual subject in the study during the maximal histamine stimulation period before and after an intravenous bolus dose of $200 \mathrm{mg}$ cimetidine, measured both as acid output (mmol $\left.\mathrm{H}^{+} / \mathrm{h}\right)$ and a 'pyloric loss and duodenogastric reflux' corrected volume (Vg, $m l / h)$.

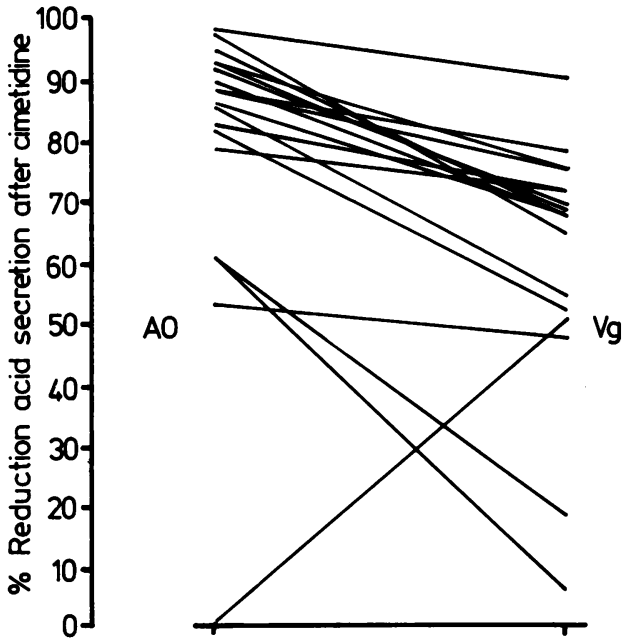

Fig. 2 Percentage reduction of acid secretion after cimetidine in each subject by acid output $(A O)$ and corrected volume $(\mathrm{Vg})$ methods.

in reflux after cimetidine accounts for most of the discrepancy between acid output and $\mathrm{Vg}$ calculations of acid secretion.

The Table shows the mean changes, standard deviations and ranges in gastric secretion, pyloric loss, and duodenogastric reflux after cimetidine.

Pyloric loss was variable from subject to subject and showed no significant trend before or after cimetidine administration. In only one subject was it an important factor as a reduced pyloric loss after

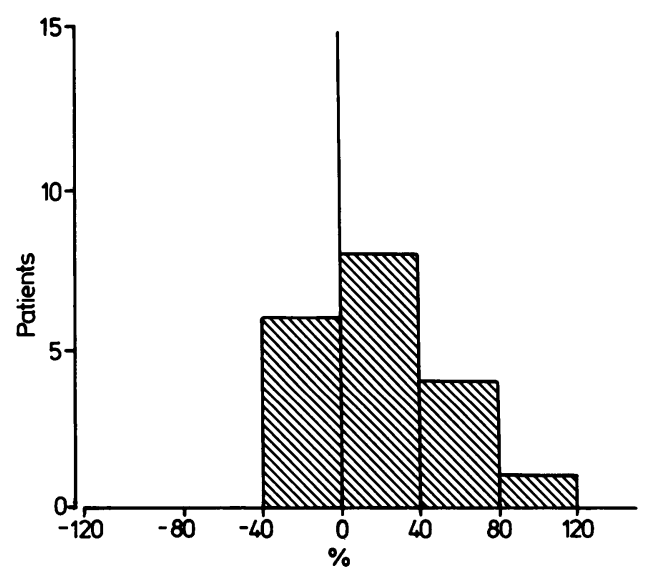

Fig. 3 Percentage change in duodenogastric reflux after an intravenous dose of $200 \mathrm{mg}$ cimetidine. 
Table Mean changes, standard deviations and ranges in gastric secretion, pyloric loss and duodenogastric reflux after cimetidine.

\begin{tabular}{|c|c|c|c|c|c|}
\hline & Mean** & $S D$ & Min & $\operatorname{Max}$ & $p^{*}$ \\
\hline $\begin{array}{l}\text { Acid output } \\
\mathrm{mmol} \mathrm{H}^{+} / \mathrm{h}\end{array}$ & $-19 \cdot 2$ & $12 \cdot 4$ & $4 \cdot 8$ & $-37 \cdot 2$ & $<0.01$ \\
\hline $\begin{array}{l}\text { Vg ml/h } \\
\text { Pyloric loss }\end{array}$ & $-169 \cdot 8$ & 49.7 & $43 \cdot 2$ & $-444 \cdot 6$ & $<0.01$ \\
\hline $\begin{array}{c}\mathrm{ml} / \mathrm{h} \\
\text { Reflux } \mathrm{ml} / \mathrm{h}\end{array}$ & $\begin{array}{r}-5 \cdot 8 \\
12 \cdot 6\end{array}$ & $\begin{array}{l}35 \cdot 3 \\
14 \cdot 9\end{array}$ & $\begin{array}{c}203 \cdot 2 \\
81\end{array}$ & $\begin{array}{r}-154.9 \\
-69.6\end{array}$ & $\begin{array}{l}\text { ns } \\
<0 \cdot 1\end{array}$ \\
\hline
\end{tabular}

* Statistical significance by the Wilcoxon's paired rank sum test. ${ }^{* *}$ Negative value indicates a decrease.

cimetidine obscured the considerable fall in gastric secretion.

In only two subjects was the rate of gastric secretion reduced to less than $60 \mathrm{ml} / \mathrm{h}$ after cimetidine.

\section{Discussion}

The histamine stimulation plateau is computer generated so as to decrease the known observer bias. $^{2}$ We chose to exclude the first 10 minute sample after cimetidine administration to allow time for a response to be seen in gastric secretion as suggested by studies in $\operatorname{dogs}^{3}$ and $\operatorname{man}^{4}$ which show a marked response to intravenous cimetidine from 15 to 30 minutes after administration.

The method of analysis used in this study allows a more consistent and reproducible way of assessing gastric secretion by calculating the pyloric loss and duodenogastric reflux errors of the gastric aspirate and showing the actual volume of gastric secretion during each period in the study. The formula quantifies reflux in terms of deviations from the concentrations of sodium ion expected at any given rate of secretion and the expected concentrations are calculated on the two-component hypothesis that pure gastric juice comprises a variable volume of an acid component and a fixed volume of an alkaline component, each of characteristic ionic composition. Other possible labels for reflux (bile salts, indocyanine green, bromsulphalein) have the disadvantage that they label bile rather than the whole of the duodenal contents and the information they give is about bile reflux rather than duodenogastric reflux. Mechanical markers of the duodenal contents have to be sited via a tube passing through the pylorus and clearly this factor may itself alter reflux. The sodium ion has the advantage of being an intrinsic marker uniformly distributed throughout the duodenal contents. Moreover, the sodium model is certainly accurate for maximally ${ }^{5}$ and submaximally ${ }^{6}$ stimulated secretion down to the rate of $60 \mathrm{ml} / \mathrm{h}$ and for achlorhydric patients. ${ }^{7}$ In the present study, only two subjects had a postcimetidine secretion rate of less than $60 \mathrm{ml} / \mathrm{h}$. There are then only two subjects whose secretion rate after cimetidine fell within the narrow band of $0-60 \mathrm{ml} / \mathrm{h}$ where the secretion formula has not been validated. Even if the formula is not applicable in these two subjects their reflux was so small as to make an insignificant contribution to the reflux of the whole group. These considerations strengthen the present conclusion than duodenogastric reflux increases after cimetidine.

Gastric secretion studies, using intravenous cimetidine and calculating acid output from the aspirate directly, gave acid inhibition rates between $80 \%$ and $90 \%{ }^{48}$ and compare closely with our result of $86 \%$. We have shown, however, that this inhibition is not as great as it appears when the gastric aspirate is corrected for pyloric loss and duodenogastric reflux. The differences in the inhibition rates are because of the increased duodenogastric reflux component of the gastric aspirate after cimetidine which, being alkaline, neutralises some of the secreted acid in the stomach. Studies linking the healing of peptic ulcers with the reduction in acid secretion because of cimetidine must consider the duodenogastric reflux component of the aspirate if they are to be accurate and avoid the thoroughly misleading results we obtained in at least three of our subjects in this study. This is not to suggest that because cimetidine reduces true gastric secretion less than was at first supposed, it is therefore likely to be less potent in healing duodenal ulcers than we might expect. The undoubted clinical efficacy of cimetidine is presumably due to its ability to raise the $\mathrm{pH}$ of gastric and duodenal contents. It may not matter whether it does this completely by reducing gastric acid secretion, or partly in that way and partly by provoking retrograde movement of duodenal contents towards the pylorus.

Duodenogastric reflux occurs when there is retrograde motor activity in the duodenum with an open pylorus. There has been no study showing that cimetidine has any inhibitory action on the pylorus. Pressure studies on the lower oesophageal sphincter (LOS) by Carter $e t$ al ${ }^{9}$ using intravenous cimetidine failed to show any significant effect, although mean pressure was decreased after the cimetidine. It is possible that a higher dose $(>100 \mathrm{mg} / \mathrm{h})$ may have produced a more obvious inhibitory effect on the sphincter. Bailey et al $^{10}$ suggested a bimodal effect of cimetidine on the LOS with an increase in LOS pressure at lower doses of cimetidine but a decrease in LOS pressure at higher doses after 30 minutes. Gastric emptying studies have shown no effect on 
the rate of gastric emptying, using single dose oral cimetidine $300 \mathrm{mg}^{11}$ and $400 \mathrm{mg}^{12}$ when compared with placebo. Intravenous cimetidine, given in the fasting state, has no effect on the phases of the interdigestive motor activity of the stomach or duodenum. ${ }^{13}$ There is therefore no convincing evidence to suggest a direct motor effect of cimetidine on the upper gastrointestinal tract or an indirect effect because of a decreased acid load reaching the duodenum. ${ }^{14}$ Serum gastrin concentrations after ora ${ }^{15}$ and intravenous ${ }^{9}$ cimetidine in the fasting state remain unchanged so could not indirectly account for a change in the motor activity of the stomach. The relationship between cimetidine and increased duodenogastric reflux remains to be solved by further studies.

We wish to thank Smith Kline and French for their donation of cimetidine for this study.

\section{References}

1 Hassan MA, Hobsley M. Positioning of subject and of nasogastric tube during a gastric secretion study. $\mathrm{Br}$ Med J 1970; 1: 458-60.

2 Whitfield PF, Hobsley M. A standard technique for the performance of accurate gastric secretion studies. Agents Actions 1979; 9: 327-32.

3 Parsons ME. The antagonism of histamine $\mathrm{H} 2$ receptors in vitro and in vivo with particular reference to the actions of cimetidine. Proceedings of 2nd International Symposium on histamine H2 receptor antagonists. Amsterdam: Excerpta Medica, 1977: 1320.

4 Sewing K-FR, Billian A, Malchow A. Comparative study with ranitidine and cimetidine on gastric secre- tion in normal volunteers. Gut 1980; 21: 750-2.

5 Hobsley M. Pyloric reflux: a modification of the two-component hypothesis of gastric secretion. Clin Sci Mol Med 1974; 47: 131-41.

6 Hobsley M, Silen W. The relationship between the rate of production of gastric juice and its electrolyte concentration. Clin Sci 1970; 39: 61-75.

7 Gardham JRC, Hobsley M. The electrolytes of alkaline human gastric juice. Clin Sci 1970; 39: 77-87.

8 Domschke W, Lux G, Domschke S. Gastric inhibitory action of $\mathrm{H} 2$-antagonists ranitidine and cimetidine. Lancet 1979; 1: 320.

9 Carter DC, Osborne DH, Lennon J, Henderson M. Effect of cimetidine on lower oesophageal sphincter pressure. Proceedings of 2nd International Symposium on histamine $\mathrm{H} 2$ receptor antagonists. Amsterdam: Excerpta Medica, 1977: 135-44.

10 Bailey RJ, Sullivan SN, MacDougall BRD, Williams R. Effect of cimetidine on lower oesophageal sphincter. $\mathrm{Br}$ Med J 1976; 2: 678.

11 Richardson CT, Walsh JH, Hicks MI. The effect of cimetidine, a new histamine $\mathrm{H} 2$-receptor antagonist, on meal-stimulated acid secretion, serum gastrin, and gastric emptying in patients with duodenal ulcer. Gastroenterology 1976; 71: 19-23.

12 Heading RC, Logan RFA, McLoughlin GP, Lidgard G, Forrest JAH. Effect of cimetidine on gastric emptying. Proceedings of the 2nd International Symposium on histamine $\mathrm{H} 2$ receptor antagonists. Amsterdam: Excerpta Medica, 1977: 145-54.

13 Rees WD, Miller LJ, Malagelada J-R, Go VLW. Role of gastric acid secretion in the generation of human interdigestive motor activity. [Abstract] Gut 1978; 19: A997.

14 Cooke AP. Control of gastric emptying and motility. Gastroenterology 1975; 68: 804-16.

15 Bank S, Barbezat GO, Vinik AI, Halter F, Helman CA. Cimetidine and serum gastrin levels in man. Proceedings of 2nd International Symposium on histamine $\mathrm{H} 2$ receptor antagonists. Amsterdam: Excerpta Medica, 1977: 155-62. 